\title{
Mengupas Type Models, Frameworks, Dimensi, dan Definisi: Literatur Review Entrepreneurial Marketing 10 Tahun Terakhir
}

\author{
Authors: \\ Adjie Ahmad Darajat ${ }^{1}$ \\ Muhamad Rizal ${ }^{2}$ \\ Ria Arifianti ${ }^{3}$ \\ Affiliation: \\ ${ }^{1,2,3}$ Departemen Administrasi \\ Bisnis, Fakultas Ilmu Sosial \\ dan Ilmu Politik, Universitas \\ Padjadjaran \\ Corresponding Author: \\ Adjie Ahmad Darajat \\ Emails: \\ 1adjieahmad19001@mail.unpad.a \\ c.id \\ ${ }^{2}$ m.rizal@unpad.ac.id \\ 3r.arifianti@mail.unpad.ac.id
}

Article History:

Received: December 18, 2019

Revised : May 10, 2020

Accepted: May 26, 2020

How to cite this article: Darajat, A. A., Rizal, M., \& Arifianti, R. (2020). Mengupas Type Models, Frameworks, Dimensi, dan Definisi: Literatur Review Enterpreneurial Marketing 10 Tahun Terakhir. Organum: Jurnal Saintifik Manajemen dan Akuntansi, 3(1), 22-36. doi:

https://doi.org/10.35138/organu m.v3i1.63

Journal Homepage: ejournal.winayamukti.ac.id/ind ex.php/Organum

\section{Copyright:}

C) 2020. Published by

Organum: Jurnal Saintifik

Manajemen dan Akuntansi.

Faculty of Economics and

Business. Winaya Mukti

University.
Abstract. Research on Marketing and Entrepreneurship has been developing for years, even now. Entrepreneurial Marketing (EM), was born from the practice of companies operating in conditions of uncertainty and emerged as a compelling alternative to overcoming the declining effectiveness associated with traditional marketing practices. In this article, the author provides a comprehensive review of the type models, frameworks, dimensions, and definitions. In total, three types of research interest: first, related research related to the range of the development of the concept of EM type models and EM frameworks, second, to explore the development of EM dimensions, the third to explore the comparison of definitions, the difference between EM and traditional marketing in EM research in the last ten years.

Keywords: Entrepreneurial marketing; EM definition; EM dimension; EM type models and Frameworks.

Abstrak. Penelitian tentang marketing dan entrepreneurship telah berkembang selama bertahun-tahun bahkan sampai saat ini. Entrepreneurial Marketing (EM), lahir dari praktik perusahaan yang beroperasi di dalam kondisi penuh ketidakpastian, dan muncul sebagai alternatif yang kuat untuk mengatasi menurunnya efektivitas yang berhubungan dengan praktik marketing secara tradisional. Dalam artikel ini, penulis memberikan tinjauan yang komprehensif tentang type models, frameworks, dimensi, dan definisi. Secara keseluruhan, tiga jenis minat penelitian; pertama penelitian yang berhubungan dengan jangkauan pengembangan konsep EM type models dan frameworks EM, kedua mengupas perbandingan perkembangan dimensi EM, ketiga mengupas perbandingan definisi, perbedaan antara EM dengan marketing tradisional pada penelitian EM sepuluh tahun terakhir.

Kata Kunci: Entrepreneurial marketing; definisi EM; dimensi EM; type models dan frameworks EM.

\section{Pendahuluan}

$\mathrm{P}$ enelitian tentang marketing dan entrepreneurship telah berkembang selama bertahun-tahun bahkan sampai saat ini. Entrepreneurial marketing, lahir dari praktik marketing perusahaan yang beroperasi dalam kondisi penuh ketidakpastian, dan muncul sebagai alternatif yang kuat untuk mengatasi menurunnya efektivitas yang berhubungan dengan praktik pemasaran yang dilakukan secara tradisional.

Istilah 'Entrepreneurial Marketing' (EM) menandakan bidang penelitian yang relatif muda, sangat dinamis dan 
mungkin menjadi terkenal karena menggabungkan dua bidang penelitian yang terkenal, 'Entrepreneurship' dan 'Marketing', yang memiliki banyak keterkaitan dan hubungannya (Kraus, Filser, Eggers, Hills, \& Hultman, 2012). Namun, hubungan antara kedua disiplin tersebut belum diselidiki secara cukup, meskipun studi di lapangan telah banyak dilakukan sejak konferensi pertama tentang EM diadakan pada tahun 1986 (Kraus et al., 2012).

Sudah banyak yang diketahui tentang Entrepreneurial Marketing (EM) sehingga penulisan artikel ini apakah bisa memberikan kontribusi untuk penelitian EM pada strategi dan/atau literatur entrepreneurship? Penulis percaya bahwa sudah saatnya EM telah mencapai titik untuk membuka bab baru, pekerjaan awal dalam lingkup ini berfokus pada isu-isu yang terkait dengan bertumpuknya antara teori marketing konvensional dan teoriteori yang dianjurkan oleh entrepreneurship (Hills, Hultman, \& Miles, 2008). Kemajuan penelitian lebih lanjut telah menjadi identifikasi dan konseptualisasi teori akademik entrepreneurial marketing secara spesifik (Morris, Schindehutte, \& LaForge, 2002), dilengkapi dengan teori pelaksanaan entrepreneurial marketing.

$\begin{array}{crr}\text { Sedangkan, } & \text { riset } & \text { tentang } \\ \text { entrepreneurial } & \text { marketing } & \text { telah }\end{array}$
berkembang secara mendalam sejak 1980an. Cara pemasaran ini telah dilakukan oleh perusahaan kecil ketika para pemiliknya melakukan pendekatan entrepreneurship (Morris, Schindehutte, \& LaForge, 2002).

Dengan meninjau literatur dari cakupan penelitian yang dinamis selama 10 tahun terakhir, artikel ini berupaya mengelompokkan berbagai pendekatan dan teori serta konsep yang digunakan. Tujuan penelitian ini memiliki tiga tujuan, yaitu 1) mengupas dan membandingkan type model dan framework $\mathrm{EM} ; 2$ ) mengupas perbedaan dimensi entrepreneurial marketing; EM dimension; dan 3) mengupas perbedaan EM definition dalam 10 tahun terakhir.

Dalam artikel ini, penulis akan memberikan sudut pandang secara umum, untuk mencoba mengembangkan pandangan secara komprehensif tentang EM dan bertujuan untuk membandingkan berbagai penelitian EM dan mengidentifikasi kesenjangan teoretis dalam penelitian ini untuk panduan menuju penelitian EM selanjutnya.

\section{Kajian Literatur}

\section{Apa itu entrepreneurial marketing?}

EM kemungkinan menjadi konsep yang sejauh ini sulit dipahami, salah satu potensi alasan kesulitan ini mungkin dikarenakan setiap konsep dapat ditafsirkan dengan berbagai cara, mungkin dikarenakan ada banyak kombinasi dari konseptualisasi keterkaitan antara entrepreneurship dan marketing (Kraus, Harms, \& Fink, 2010).

EM bisa dikatakan tentang suatu tindakan pemasaran yang dilakukan oleh para pengusaha, owner bisnis, sedangkan manajemen pemasaran secara tradisional biasanya merupakan tindakan pemasaran yang dilakukan oleh seorang manajer pemasaran (Hills, Morgan, \& Hultman, 2010). Namun, pada tingkat yang lebih rumit, arti EM juga menjadi lebih kompleks. EM dapat dilihat sebagai bagian penting dari disiplin entrepreneurship yang muncul dari pemikiran baru dalam disiplin pemasaran.

Pada tahap awal merujuk definisi dari American Marketing Association (AMA) tentang marketing (2007) adalah "...the activity, set of institutions and processes for creating, communicating, delivering and exchanging offerings that have value for customers, clients, partners and society at large" (Hills, Morgan, \& Hultman, 2010). Definisi tersebut terdapat bahwa sebagian besar definisi pemasaran terkait erat dengan definisi entrepreneurship dan ini tidak ada pengecualian. Bidang entrepreneurship 
yang melibatkan sumber proses pencarian penemuan suatu peluang, mengevaluasi, dan mengeksploitasi peluang tersebut dan cenderung terhadap individu yang menggerakannya (Hills, Morgan, \& Hultman, 2010).

\section{Siapa, dimana, dan kapan entrepreneurial marketing?}

Entrepreneurial marketing lebih sering ditemui pada perusahaan kecil dari pada perusahaan besar, karena perusahaan besar cenderung menghadapi hambatan internal yang kuat untuk pendekatan secara entrepreneurship. Konsep ini sering dihubungkan dengan langkahlangkah pemasaran yang cenderung menantang kebiasaan pasar yang sudah stabil (Morris, Schindehutte, \& LaForge, 2002). Semua ini lebih didorong berdasarkan pencarian peluang dibandingkan penerapan secara administrasi pada konsep pemasaran tradisional, (Hills, Hultman, \& Miles, 2008) mengintegrasikan pemasaran dengan mengutamakan inovasi, dan ini merupakan sumber utama entrepreneurhsip.

Mekanisme value creation dalam entrepreneurial marketing dianggap inovatif yang menyimpang dari konsep pemasaran konvensional dan pemasaran secara administrasi dalam aspek-aspek seperti bertatap muka dengan pelanggan, manajemen risiko, dan peningkatan sumber daya (Morris, Schindehutte, \& LaForge, 2002).

Hills, Hultman, \& Miles (2008) mengamati bahwa non-traditional marketing seperti EM sering berkaitan dengan beberapa kondisi berikut:

1) kurangnya skala perekonomian;

2) kendala sumber daya yang terbatas;

3) keberadaan pasar geografis yang terbatas;

4) limited market image;

5) little brand loyalty or market share;

6) sedikit ahli profesional dalam jajaran manajemen;
7) pengambilan keputusan dalam kondisi imperfect information pada perusahaan besar;

8) keterbatasan waktu untuk tugas utama manajemen;

9) keterbatasan manajer profesional; dan

10) tujuan bisnis dan tujuan pribadi tercampur.

Mereka mengamati bahwa marketing dipandang dan dilakukan secara berbeda dalam konteks di mana variabel ini berlaku dan EM dapat dilihat sebagai jangkauan untuk masalah terkait marketing (Hills, Hultman, \& Miles, 2008).

\section{Mengapa dan bagaimana entrepreneurial marketing?}

Konsumen saat ini memiliki harapan yang tinggi terhadap kualitas interaksi mereka dengan bisnis, studi pemasaran dan manajemen baru-baru ini berfokus pada konsumen berpengetahuan modern dan diskriminatif, harapan ini menghadirkan peluang dan tantangan bagi para entrepreneur untuk membangun hubungan melalui upaya pemasaran mereka dengan pelanggan dan mengembangkan sumber keunggulan kompetitif (Fiore, Niehm, Hurst, Son, \& Sadachar, 2013).

Perkembangan teknologi dan selera konsumen yang cepat menciptakan kondisi ketidakpastian, yang membuat strategi pemasaran tradisional dan taktik tidak efektif (Reibstein, Day, \& Wind, 2009). Namun, EM muncul sebagai alternatif baru yang kuat, karena lahir dari teori dan praktik perusahaan yang beroperasi dalam kondisi penuh dengan ketidakpastian (Morris, Schindehutte, \& LaForge, 2002). Oleh karena itu, gagasan tentang EM pada kondisi tersebut sangat penting dalam rangka pengembangan bisnis kontemporer karena entrepreneurship dan pemasaran berpotensi saling melengkapi.

EM yang berkaitan dengan promosi didasarkan pada komunikasi dari mulut ke mulut dan pengembangan 
direkomendasikan langsung berdasarkan basis pelanggan, pendekatan ini mungkin lebih menghemat biaya dari pada memasang iklan secara klasik (Stokes, 2000).

Ada tiga bentuk penerapan EM yang paling terkenal dan paling sukses dalam hal pendekatan entrepreneurship untuk promosi: guerilla marketing, buzz marketing, dan viral marketing. Ketiga bentuk ini sebagian bertumpuk, karena semuanya didasarkan pada konsep pemasaran dari mulut ke mulut (Kraus, Harms, \& Fink, 2010).

\section{Metode Penelitian}

Tinjauan sistematis literatur dalam penelitian ini terkait dengan entrepreneurial marketing. Tinjauan literatur sistematis digunakan karena baik untuk mencari, memilih, menganalisis, menilai dan mengevaluasi literatur yang relevan dengan pertanyaan penelitian tertentu (Briner \& Denyer, 2012).

Untuk itu, literatur yang digunakan dalam penelitian ini diambil dari beberapa artikel dan hanya berasal dari database yang diindeks oleh Scopus, hal ini dikarenakan sebagai upaya untuk mengumpulkan artikel dengan kualitas tinggi terkait dengan sistem pendukung keputusan dalam penulisan. Data literatur berdasarkan tahun 2010-2019 digunakan dalam penelitian ini, yang diperoleh dengan kata kunci "entrepreneurial marketing".

Penelitian ini bertujuan secara sistematis untuk mencari artikel yang terkait dengan pembahasan topik berkaitan dengan EM dan di dalam artikelnya terdapat pandangan type, frameworks, dimensi, dan definisi EM. Untuk alasan ini, tinjauan sistematis artikel ini hanya menyelidiki satu topik yang dilakukan kata kunci: "entrepreneurial marketing". Basis data yang digunakan untuk memilih artikel hanya dari Scopus untuk menemukan artikel terkait. Basis data ini dipilih karena Scopus hanya menghasilkan artikel peer- review dan dapat diandalkan. Database menunjukkan total 153 artikel diidentifikasi dari berbagai jurnal dan penerbit. Kriteria dalam memilih artikel termasuk artikel harus dalam bahasa Inggris; teks lengkap tersedia sesuai dengan tinjauan sistematis dan topik penelitian yang berhubungan ke dalam pertanyaan penelitian ini; dan terbatas pada jurnal dan database yang telah ditentukan sebelumnya.

Tiga penyaringan dilakukan untuk mendapatkan artikel. Penyaringan pertama adalah untuk menghilangkan duplikat artikel dan menemukan artikel yang relevan sebanyak 31 sampai menghasilkan artikel yang tersisa adalah 122. Selanjutnya dalam penyaringan kedua, dari jumlah artikel yang tersisa, kami telah menyaring artikel dalam hal judul dan abstrak berdasarkan kesesuaian artikel dengan topik pada tinjauan sistematis ini. Hasil penyaringan artikel tersebut telah menghasilkan penghapusan 75 artikel dan diperoleh 47 artikel. Screening ketiga termasuk pembacaan lengkap, dalam screening ini menghasilkan penghapusan 21 artikel dan 26 artikel ditemukan bermanfaat dalam tinjauan sistematis dalam penelitian ini.

\section{Hasil dan Pembahasan EM Type Models dan Frameworks}

EM adalah bidang penelitian yang sedang berkembang dan menjadi pemikiran signifikan (Hills \& Hultman, 2013; Hills, Hultman, \& Miles, 2008; Kraus, Eggers, Harms, Hills, \& Hultman, 2011). Model EM yang membenarkan hubungan antara entrepreneurship, marketing, dan inovasi (Jones \& Rowley, 2009). Banyak peneliti menyoroti integrasi marketing secara generik dengan pure entrepreneurialism (Duus, 1997; Hills \& Laforge, 1992; Stokes, 2000). Peneliti lain menghubungkan entrepreneurial marketing dengan pengusaha dan korporatisme sebagai prosesnya dari pada fungsinya (Miles \& Darroch, 2006), serta mencakup orientasi kegiatan 
entrepreneurship (Collinson \& Shaw, 2001; Morris, Schindehutte, \& LaForge, 2002). Perkembangan lebih lanjut ada di dalam bidang khusus dan niche area seperti teknologi, social entrepreneurship, ekonomi, penelitian, dan non-for profit
(Duus, 1997; Hill \& Wright, 2000; Morris, Schindehutte, \& LaForge, 2002; Quinton \& Harridge-March, 2006; Shaw, 2004). Dalam Tabel 1 penulis menyajikan type dan frameworks yang paling penting dalam perubahan EM.

\section{Tabel 1. EM Type Models dan Frameworks}

\begin{tabular}{|c|c|c|}
\hline Author & Model Component & Type Model \\
\hline $\begin{array}{l}\text { Morrish, Miles, and } \\
\text { Deacon }(2010: 308)\end{array}$ & $\begin{array}{l}\text { The entrepreneur and the customer as } \\
\text { equivalent core actors, EM as culture, } \\
\text { EM as strategy, EM shaping product, } \\
\text { price, place, and promotion. }\end{array}$ & $\begin{array}{l}\text { An entrepreneurial } \\
\text { marketing perspective } \\
\text { (acknowledging the } \\
\text { entrepreneur and } \\
\text { customer-centric } \\
\text { interrelationship) }\end{array}$ \\
\hline $\begin{array}{l}\text { Kraus, Harms, and } \\
\text { Fink (2010) }\end{array}$ & $\begin{array}{l}\text { Guerrilla marketing, Buzz marketing, } \\
\text { Viral marketing external }\end{array}$ & $\begin{array}{l}\text { Forms of } \\
\text { entrepreneurial } \\
\text { marketing in the domain } \\
\text { of promotion }\end{array}$ \\
\hline $\begin{array}{l}\text { Maritz }(2010, \\
\text { diadaptasi dari } \\
\text { Moriss, 2002) }\end{array}$ & $\begin{array}{l}\text { External environment (economic, social, } \\
\text { technological factor), Internal venture } \\
\text { environment (MO,EO, VCV), Venture } \\
\text { approach to marketing (innovations, } \\
\text { communication, and venture outcome) }\end{array}$ & $\begin{array}{l}\text { A model of application } \\
\text { for entrepreneurial } \\
\text { marketing }\end{array}$ \\
\hline Morrish (2011) & $\begin{array}{l}\text { Entrepreneur and customers as core } \\
\text { actors of EM strategy }\end{array}$ & $\begin{array}{l}\text { Entrepreneurial } \\
\text { marketing: a strategy } \\
\text { for the twenty-first } \\
\text { century? }\end{array}$ \\
\hline $\begin{array}{l}\text { Jones \& Rowley } \\
\text { (2011: 31) }\end{array}$ & $\begin{array}{l}\text { Market orientation, Entrepreneurial } \\
\text { orientation, Innovation orientation, and } \\
\text { Customer orientation }\end{array}$ & $\begin{array}{l}\text { The SME } \\
\text { Entrepreneurial } \\
\text { Marketing Orientation } \\
\text { (EMO) Conceptualize } \\
\text { Model } \\
\text { framework). }\end{array}$ \\
\hline $\begin{array}{l}\text { Hills \& Hultman } \\
\text { (2011) }\end{array}$ & $\begin{array}{l}\text { Observable business environment, } \\
\text { Entrepreneurial decision-making } \\
\text { (proactive, growth-oriented, risk-taking } \\
\text { propensity, innovative and opportunity } \\
\text { oriented) and Observable marketing } \\
\text { outcomes }\end{array}$ & $\begin{array}{l}\text { Elements of } \\
\text { entrepreneurial } \\
\text { marketing } \\
\text { (Entrepreneurial } \\
\text { marketing is the result } \\
\text { of entrepreneurial } \\
\text { interpretation of } \\
\text { information, decision- } \\
\text { making and marketing } \\
\text { actions) }\end{array}$ \\
\hline $\begin{array}{l}\text { Swenson, Rhoads \& } \\
\text { Whitlark (2012) }\end{array}$ & $\begin{array}{l}\text { Creating opportunity, making profits, } \\
\text { multiplying the effect, accelerating the } \\
\text { process and leveraging relationships }\end{array}$ & $\begin{array}{l}\text { Entrepreneurial } \\
\text { marketing: a framework } \\
\text { for creating opportunity } \\
\text { with competitive angles }\end{array}$ \\
\hline
\end{tabular}




\begin{tabular}{|c|c|c|}
\hline $\begin{array}{l}\text { Mort, } \\
\text { Weerawardena, \& } \\
\text { Liesch (2012) }\end{array}$ & $\begin{array}{l}\text { Opportunity creation, customer } \\
\text { intimacy-based innovative products, } \\
\text { resource enhancement, and legitimacy. }\end{array}$ & $\begin{array}{l}\text { Four key strategies } \\
\text { underpinning } \\
\text { entrepreneurial } \\
\text { marketing comprising }\end{array}$ \\
\hline Solé (2013: 33) & $\begin{array}{l}\text { Entrepreneurial Orientation } \\
\begin{array}{l}\text { Market Orientation } \\
\text { (Entrepreneurial }\end{array} \\
\text { Orientation), } \\
\text { Entrepreneurship }(M E), \text { Earketing } \\
\text { Marketing }(\text { EM) and Performance } \\
\text { Marketable }\end{array}$ & $\begin{array}{l}\text { A causal model of EM } \\
\text { backgrounds on } \\
\text { performance conceptual }\end{array}$ \\
\hline $\begin{array}{l}\text { Hallback \& } \\
\text { Gabrielsson (2013) }\end{array}$ & $\begin{array}{l}\text { External environmental conditions } \\
\text { (turbulence, market orientation, global } \\
\text { growth phase, international } \\
\text { entrepreneurial marketing strategy, } \\
\text { strategic fit, and marketing } \\
\text { performance) }\end{array}$ & $\begin{array}{l}\text { Conceptual model of the } \\
\text { development of } \\
\text { international } \\
\text { entrepreneurial } \\
\text { marketing strategies in } \\
\text { INVs. }\end{array}$ \\
\hline $\begin{array}{l}\text { Fiore, Niehm, } \\
\text { Hurst, Son, \& } \\
\text { Sadachar. (2013) }\end{array}$ & $\begin{array}{l}\text { Entrepreneurial Intentions (antecedent), } \\
\text { EM, 5Ps (property, product, product } \\
\text { presentation, promotional activities, and } \\
\text { people), 4Es (educational, esthetic, } \\
\text { entertainment and escapist experience) } \\
\text { and Brand distinctiveness (consequence) }\end{array}$ & $\begin{array}{l}\text { EM scale white } \\
\text { antecedent } \\
\text { variable, consequence } \\
\text { variable and brand } \\
\text { distinctiveness }\end{array}$ \\
\hline $\begin{array}{l}\text { Franco, Santos, } \\
\text { Ramalho, \& Nunes } \\
(2014: 278)\end{array}$ & $\begin{array}{l}\text { Entrepreneurial marketing: } \\
\text { Communication, } \\
\text { Entrepreneur characteristics, and } \\
\text { Marketing practices }\end{array}$ & $\begin{array}{l}\text { Key dimensions and } \\
\text { variables associated } \\
\text { with entrepreneurial } \\
\text { marketing in SMEs }\end{array}$ \\
\hline $\begin{array}{l}\text { Miles, Gilmore, } \\
\text { Harrigan, Lewis, \& } \\
\text { Sethna (2014) }\end{array}$ & $\begin{array}{l}\text { (1) EM as entrepreneurship in } \\
\text { marketing, (2) EM as networks and } \\
\text { relationships in the context of SME } \\
\text { marketing, and (3) EM as marketing in } \\
\text { entrepreneurship. }\end{array}$ & $\begin{array}{l}\text { Typology of the three } \\
\text { schools of } \\
\text { entrepreneurial } \\
\text { marketing thought to } \\
\text { reflect the emergence of } \\
\text { different perspectives of } \\
\text { EM }\end{array}$ \\
\hline $\begin{array}{l}\text { Miles, Gilmore, } \\
\text { Harrigan, Lewis, \& } \\
\text { Sethna (2014: 10) }\end{array}$ & $\begin{array}{l}\text { EM as: (1) vertical -top management, } \\
\text { upper echelons dimension; (2) } \\
\text { horizontal-EM as a process exclusively } \\
\text { for the marketing functional area; and } \\
\text { (3) temporal-EM as simply a stage of } \\
\text { the evolution of marketing in an } \\
\text { organization or a market }\end{array}$ & $\begin{array}{l}\text { A typology of where EM } \\
\text { could be manifested } \\
\text { within a through a } \\
\text { firm oxplores } \\
\text { framework that explational } \\
\text { the organizativens of EM } \\
\text { pervasiveness }\end{array}$ \\
\hline $\begin{array}{l}\text { Whalen et al. } \\
\text { (2015) }\end{array}$ & $\begin{array}{l}\text { Opportunity recognition, } \\
\text { resources (Knowledge, } \\
\text { Entrepreneurial organization, Operant } \\
\text { resources (Factor of production), } \\
\text { Environmental turbulence (market, } \\
\text { competitive, technological), } \\
\text { Entrepreneurial Marketing, Temporary } \\
\text { competitive advantage }\end{array}$ & $\begin{array}{l}\text { An entrepreneurial } \\
\text { marketing contingency } \\
\text { framework. }\end{array}$ \\
\hline
\end{tabular}


Ada type model dan frameworks yang menunjukkan bahwa banyak analisis tentang faktor-faktor penentu EM serta dampak yang diberikan oleh kinerjanya. Ada beberapa penelitian terdahulu tentang EM diantaranya, yaitu penelitian mengeksplorasi secara psikologi para manajer atau founder (Carson \& Gilmore, 2000), yang lainnya memeriksa dampak pengaruh terhadap lingkungan dan organisasi EM (Fiore et al., 2013; Hills \& Hultman, 2011; Maritz, Frederick, \& Valos, 2010; Miles, Gilmore, Harrigan, Lewis, \& Sethna, 2014; Morris et al., 2002), dan teradapat juga dilihat dari konteks strategis EM (Hallbäck \& Gabrielsson, 2013; Hills \& Hultman, 2011; Morrish, 2011; Mort, Weerawardena, \& Liesch, 2012) dan hubungan EM untuk memacu kemampuan sumber daya (Miles et al., 2014; Morris et al., 2002; Whalen et al., 2015). Trend penelitian terbesar saat ini meneliti tentang kinerja EM, pada lingkungan dan strategi yang berbeda, dan diatur di berbagai kondisi yang tidak pasti (Fiore et al., 2013; Hallbäck \& Gabrielsson, 2013; Hills \& Hultman, 2011; Maritz et al., 2010; Morris et al., 2002; Solé, 2013; Whalen et al., 2015). Kemajuan metodologi dari pendalaman yang kompleksitas terhadap type model yang dikembangkan dan diuji langsung cenderung berkembang jauh dari waktu ke waktu. Type model ini juga yang memungkinkan untuk hubungan timbal balik antara EM dan faktor lingkungan, strategis, dan internal (Fiore et al., 2013; Mort et al., 2012). Terlepas dari perhatian luar biasa yang telah diterima EM dan terlepas dari kemajuan konseptual empiris yang telah dibuat oleh begitu banyak penelitian yang sangat baik, masih banyak perdebatan tentang pendorong dan pengaruh EM dan bahkan penilaiannya (Franco, Santos, Ramalho, \& Nunes, 2014; Jones \& Rowley, 2011; Morris et al., 2002).

\section{Dimensi EM}

Fokus dari sudut pandang EM adalah pada marketing yang dilakukan dengan menggunakan pendekatan entrepreneurship, inovatif, dan didorong oleh opportunity (Fiore et al., 2013; Morrish, Miles, \& Deacon, 2010). Penelitian sebelumnya mengidentifikasi beberapa karakteristik perilaku EM, seperti perhitungan risk taking (Hills \& Hultman, 2011), keputusan berdasarkan keahlian dan naluri, fokus yang melekat terhadap inovasi (Hills \& Hultman, 2013; Morrish, 2011; Whalen et al., 2015), fokus yang melekat pada pengenalan peluang, pendekatan yang fleksibel untuk pasar \& calon pasar (Shaw, 2004), dan eksploitasi celah pasar yang lebih kecil (Stasch, 2002). Dalam Tabel 2 penulis menyajikan dimensi EM dari 10 tahun terakhir.

Sejumlah perdebatan telah muncul dalam literatur yang berhubungan dengan sifat konsep dan dimensinya (Hills et al., 2008; Morris et al., 2002) dimensi yang saling ketergantungan, sifat dimensi (Hills et al., 2008), dan hubungan konsep teoretis antara konsep antecedent dan concequence (Hills et al., 2008). Masing-masing masalah ini terkait erat dengan definisi konsep teoritis dan menggambarkan bahwa sangat penting bahwa kita mencapai kesepakatan pada definisi jika kita ingin melakukan penelitian dengan substantif tentang EM.

Tabel 2. EM Dimension

\begin{tabular}{lll}
\hline Author & Dimension & Explanation \\
\hline Hills \& Hultman & Innovativeness, creativity, selling, \\
(2011: 6) & $\begin{array}{l}\text { market immersion, networking, and } \\
\text { flexibility. }\end{array}$ \\
\hline
\end{tabular}




\begin{tabular}{|c|c|c|}
\hline $\begin{array}{l}\text { Fiore et al. (2013: } \\
70)\end{array}$ & $\begin{array}{l}\text { Proactive orientation, opportunity- } \\
\text { driven, customer-intensity, innovation- } \\
\text { focused, risk-management, and value } \\
\text { creation. }\end{array}$ & \\
\hline Whalen et al. (2015) & $\begin{array}{l}\text { Innovative, proactive, and risk-taking } \\
\text { activities (risk, opportunity, and market } \\
\text { uncertainty) }\end{array}$ & \\
\hline $\begin{array}{l}\text { Morrish \& Jones } \\
\text { (2019) }\end{array}$ & $\begin{array}{l}\text { Opportunity-seeking, } \\
\text { organizing, creating new value and } \\
\text { accepting the risk }\end{array}$ & $\begin{array}{l}\text { Business disaster } \\
\text { recovery; } \\
\text { Entrepreneurial } \\
\text { marketing }\end{array}$ \\
\hline
\end{tabular}

\section{Definisi EM}

Definisi entrepreneurial marketing "telah digunakan dalam berbagai cara, dan seringkali masih terlihat renggang" (Morris et al., 2002). Banyak keraguan yang muncul dikarenakan setiap istilah EM dapat diartikan berbeda-beda. Oleh karena itu, berbagai keterkaitan dapat dibangun, EM dapat digabungkan sebagai marketing for entrepreneurs (mis. New Venture Marketing; Entrepreneurship for Marketing; Inovative Marketing (Morris et al., 2002); atau marketing for entrepreneurial firm (yang ditujukan untuk perkembangan dan inovasi (Atuahene-Gima \& Ko, 2001). Entrepreneurial marketing yang merupakan praktik dan tindakan entrepreneurship yang bisa dikatakan sebuah pola pikir yang tidak sama dengan praktik formal marketing. Sikap proaktif yang berfokus terhadap perubahan. Karena ada banyak definisi berbeda untuk entrepreneurship dan marketing di dalamnya.

Banyak bahkan bisa sampai jutaan definisi untuk entrepreneurial marketing. Di satu sisi, (Morris et al., 2002) mengidentifikasi pemikiran penggunaan istilah EM dan merujuk pada kegiatan marketing di perusahaan yang memiliki sumber daya yang terbatas dan menerapkan marketing dengan cara yang tidak modern. Ada beberapa penelitian yang menggambarkan tindakan marketing visioner non-linear yang tidak direncanakan oleh para entrepreneur sebagai EM. Tabel 3 berisi definisi EM, yang dianggap sesuai untuk penyajian dalam penulisan ini.

Memang, beberapa definisi merujuk secara jelas untuk marketing dalam usaha kecil (Hill \& Wright, 2000) serta tidak membuat referensi yang jelas untuk ukuran atau usia pada sebuah perusahaan (Morris et al., 2002), cara marketing yang menyimpang dari mainstream marketing, kegiatan marketing di perusahaan yang sedang mengarah ke arah perkembangan, kegiatan marketing di perusahaan yang sudah mapan dan sukses, kegiatan entrepreneurial marketing di perusahaan besar (Miles \& Darroch, 2006), dan lainlain, lebih fokus pada aspek kualitatif EM seperti inovasi (Stokes \& Stokes, 2000) atau value creation (Morris et al., 2002). Dari beberapa literatur yang diteliti, muncul dua sudut pandang: yaitu definisi yang melihat sudut pandang EM secara kuantitatif sebagai aspek marketing dari perusahaan untuk usaha kecil, dan kedua menyoroti aspek kualitatif EM dengan mendefinisikannya sebagai marketing dengan semangat entrepreneurship (Kraus, Harms, \& Fink, 2010). Ini dapat dilihat sebagai dua sisi yang sama, karena karakteristik kuantitatif tampaknya menjadi konteks yang mendukung kegiatan tindakan marketing yang didorong oleh semangat entrepreneurship yaitu inovatif, pemanfaatan peluang, management risiko dan proaktif. Karakteristik kualitatif (Miller, 2011). EM adalah konsep yang tidak selalu terkait dengan ukuran perusahaan, usia atau 
sumber dayanya (Ioniţă, 2012). EM adalah konsep yang dapat dipahami hanya dengan mengintegrasikan entrepreneurship ke dalam proses marketing (Hultman, 1999). Karena itu, membawa elemen baru atau memperkuat elemen yang ada, seperti fokus pada perubahan, sikap inovatif, dan peka terhadap peluang.

Di sini penulis mengambil definisi EM pada tahun 1992, "There is an opportunity in the entrepreneurship field to develop middle-range theories analogous to developments in the marketing discipline, paralleling those in consumer behavior" (Hills \& Laforge, 1992: 53). "Entrepreneurial marketing is a configuration of activities that emerge from entrepreneur decisions and actions for pursuing business objectives in stable and turbulent environments that incorporate opportunity-seeking, resourceorganizing, and risk-accepting behaviors to create multiple stakeholder values" (Morrish \& Jones, 2019), dan akan mengulas definisi EM pada 10 tahun terakhir. Berikut penulis menjabarkan pada Tabel 3 definisi EM dari 10 tahun terakhir.

Tabel 3 Definisi Entrepreneurial Marketing (EM)

\begin{tabular}{|c|c|}
\hline Author & $\begin{array}{ll}\text { Definition } & \begin{array}{l}\text { Conceptual } \\
\text { Background }\end{array} \\
\end{array}$ \\
\hline $\begin{array}{l}\text { Kraus et al. } \\
(2010: 9)\end{array}$ & $\begin{array}{l}\text { "Entrepreneurial marketing is an Function and process } \\
\text { organizational function, and a set of marketing } \\
\text { processes for creating, communicating and entrepreneurship } \\
\text { delivering value to customers and for economic theories } \\
\text { managing customer relationships in ways } \\
\text { that benefit the organization and its } \\
\text { stakeholders, and that is characterized by } \\
\text { innovativeness, risk-taking, proactiveness, } \\
\text { and may be performed without resources } \\
\text { currently controlled" }\end{array}$ \\
\hline $\begin{array}{l}\text { Morrish et al. } \\
(2010)\end{array}$ & $\begin{array}{l}\text { EM concept is the proposition that Competitive } \\
\text { competitive advantage is obtained by advantage } \\
\text { uniquely positioning product offerings that } \\
\text { are both cheaper and different or very } \\
\text { different; perhaps achieved by combining } \\
\text { unique elements such as branding and } \\
\text { production methods that create new offerings } \\
\text { that are very different to those of its } \\
\text { competitors. Firms that practice EM can be } \\
\text { viewed as an entrepreneurial firm } \\
\text { irrespective of whether it is large or small }\end{array}$ \\
\hline $\begin{array}{l}\text { Hills et al. } \\
(2010: 6)\end{array}$ & $\begin{array}{l}\text { "EM is a spirit, orientation, as well as a Marketing } \\
\text { process of pursuing opportunities and orientation, } \\
\text { launching and growing ventures that create entrepreneurship } \\
\text { perceived customer value through orientation, } \\
\text { relationships, especially by employing economic theory } \\
\text { innovativeness, creativity, selling, market } \\
\text { immersion, networking, or flexibility." }\end{array}$ \\
\hline $\begin{array}{l}\text { Maritz (2010: } \\
\text { 20) }\end{array}$ & $\begin{array}{l}\text { "Entrepreneurial marketing is the proactive } \\
\text { identification and exploitation of }\end{array}$ \\
\hline
\end{tabular}




\begin{tabular}{|c|c|}
\hline & $\begin{array}{l}\text { opportunities for acquiring and retaining } \\
\text { appropriate stakeholders through innovative } \\
\text { approaches to risk management, resource } \\
\text { leveraging, and value creation." }\end{array}$ \\
\hline $\begin{array}{l}\text { Carson (2010: } \\
\text { 9) }\end{array}$ & $\begin{array}{l}\text { "Interface researchers have been 'blinded' SMEs marketing } \\
\text { by the 'widening' of entrepreneurial } \\
\text { dominance that the true interface between } \\
\text { marketing and entrepreneurship has been } \\
\text { lost. Thus, I hope, indeed, propose that future } \\
\text { interface research is defined by the } \\
\text { parameter SB [small businesses] marketing } \\
\text { and entrepreneurship." }\end{array}$ \\
\hline $\begin{array}{l}\text { Jones \& Rowley } \\
\text { (2011: 30) }\end{array}$ & $\begin{array}{l}\text { "Any concept of EM [...] must embrace aspe EMO } \\
\text { of behaviors that have traditionally be } \\
\text { researched in the entrepreneurship, innovati. } \\
\text { and customer engagement and relations } \\
\text { fields." }\end{array}$ \\
\hline $\begin{array}{l}\text { Webb et al. } \\
(2011: 545)\end{array}$ & $\begin{array}{l}\text { "Firms can recognize and exploit Institutional theory, } \\
\text { opportunities to more efficiently or } \\
\text { effectively serve customer needs through the } \\
\text { innovation of marketing activities." }\end{array}$ \\
\hline $\begin{array}{l}\text { Morrish (2011: } \\
\text { 111) }\end{array}$ & $\begin{array}{l}\text { EM gives the entrepreneur a voice and Strategic view } \\
\text { highlights the importance of the } \\
\text { entrepreneurial process in the creation of } \\
\text { markets and artifacts; after all, it is the } \\
\text { entrepreneur that recognizes, explores and } \\
\text { exploits opportunities, found the } \\
\text { organizations and directs Subsequent } \\
\text { operational strategies (i.e., entry, growth, } \\
\text { and management) as well as strategic } \\
\text { decisions (e.g., divesting, harvesting and exit } \\
\text { decisions) all of which affect the dynamics of } \\
\text { the market. }\end{array}$ \\
\hline (Gilmore, 2011) & $\begin{array}{l}\text { The term "entrepreneurial" refers to the Strategic view } \\
\text { overall activities and behavior of } \\
\text { entrepreneurs, which includes behavior that } \\
\text { is competitive and drives the marketing } \\
\text { process. EM is subject to external change } \\
\text { factors, it is driven by the entrepreneur, it is } \\
\text { opportunistic, intuitive and if the firm is to } \\
\text { survive, it is profit-driven }\end{array}$ \\
\hline $\begin{array}{l}\text { Hills \& Hultman } \\
(2011: 6)\end{array}$ & $\begin{array}{l}\text { 'EM is a spirit, an orientation as well as a } \\
\text { process of passionately pursuing } \\
\text { opportunities and launching and growing } \\
\text { ventures that create perceived customer } \\
\text { value through relationships by employing } \\
\text { innovativeness, creativity, selling, market } \\
\text { immersion, networking, and flexibility.' }\end{array}$ \\
\hline
\end{tabular}


Ionita (2012: Entrepreneurial Marketing (EM) is a

132) theoretical construct at the nexus between marketing and entrepreneurship but insufficiently developed. Entrepreneurial thinking, which is nonlinear, creative, and avoids predictions, contradicts the traditional marketing model.

Miles et al. EM draws on the work of both marketing and EO

(2014:1) entrepreneurship scholars by focusing on

how individuals and management teams accept the risk to innovatively and proactively leverage resources to create value in the marketplace.

Whalen et al. EM is a combination of innovative, Contingency theory (2015:3) proactive, and risk-taking activities that create, communicate, and deliver value to and by customers, entrepreneurs, marketers, their partners, and society at large.

Morrish \& "Entrepreneurial marketing is a Business disaster

Jones (2019) configuration of activities that emerge from recovery, entrepreneur decisions and actions for entrepreneurial pursuing business objectives in stable and marketing turbulent environments that incorporate opportunity-seeking, resource-organizing, and risk-accepting behaviors to create multiple stakeholder values."

\section{Kesimpulan}

Di akhir artikel ini, penulis menyimpulkan akan terus ada banyak perdebatan tentang entrepreneurial marketing, driver-nya, manifestasinya, dan yang berhubungan dengan kapasitasnya. Tidak diragukan lagi, tinjauan literatur ini memiliki beberapa keterbatasan. Pertama, didasarkan pada sampel jurnal dipilih oleh penulis sesuai dengan kriteria tertentu dan hanya terbatas dari satu sumber database jurnal Scopus, sedangkan masih banyak elektronik database lain seperti Emerald, WOS, Google Scholar, dan Ebsco ini tidak mencakup seluruh jurnal akademik dalam manajemen, pemasaran dan bidang entrepreneurship. Kedua, rentang tahun terbatas pada periode 2009-2019. Untuk mengatasi keterbatasan ini, kami mencoba untuk membandingkan wawasan dari literatur terbaru dengan kontribusi yang relevan diterbitkan sebelum 2009. Ketiga, kata kunci yang digunakan hanya penggabungan satu tema "entrepreneurial marketing”. Namun, Penulis menyimpulkan "Apa itu EM?" sebagai konsep yang potensial tentu saja tidak ada konseptualisasi yang benar atau salah secara objektif. Akan tetapi, hanya ada derajat yang lebih rendah atau lebih besar di mana konseptualisasi tertentu disepakati oleh para peneliti ilmiah lain. Dengan mengenali keadaan literatur saat ini, penulis percaya sudah saatnya untuk mengenali poin-poin penting dari perbedaan dan hal-hal yang menjadi ambiguitas seputar konsep EM serta menawarkan penelitian EM yang berkualitas tinggi dan saran untuk fokus penelitian.

Di sini masih terlalu banyak sampel yang heterogen, masih sedikitnya studi kualitatif yang lebih memperdalam lagi 
pembahasan tentang EM. Variasi konsep operasional EM masih terbatas, dengan demikian masih sulit untuk mengukur penetapan validitas konvergennya. Selain itu, masih sedikit penelitian longitudinal yang membandingkan perubahan subjek penelitian setelah periode waktu tertentu. Dengan adanya gap ini akan membuat lebih sulit untuk menarik hubungan antara konteks EM pada lingkungannya, kapasitasnya dan strategisnya.

Penulis menawarkan beberapa rekomendasi sebagai masukan untuk mengembangkan lebih lanjut jangkauan untuk penelitian EM. Pertama, merangkul isu-isu konteks EM yang lebih besar (konteks dalam hal ketidakpastian lingkungan atau dinamika, struktur dan proses di dalam organisasi tertentu. Kedua, EM dan konteksnya, dengan konteks yang berbeda mungkin memiliki implikasi penting untuk batasan dan eskpektasi penelitian EM, kebanyakan studi EM memperlihatkan hasil dari pada proses EM. Ketiga, gunakan penelitian kualitatif untuk memperdalam pemahaman EM (discourse analysis, grounded theory, observasi, wawancara, detail dalam pencatatan di lapangan, dan alat etnometodologi lainnya yang dapat digunakan dalam teknik-teknik tersebut untuk melewati "who, what, where \& when" serta mengungkapkan lebih banyak tentang "why \& how".

\section{Daftar Pustaka}

Atuahene-Gima, K., \& Ko, A. (2001). An Empirical Investigation of the Effect of Market Orientation and Entrepreneurship Orientation Alignment on Product Innovation. Organization Science, 12(1), 54-74. doi:

\section{https://doi.org/10.1287/orsc.12.1.54} .10121

Briner, R., \& Denyer, D. (2012). Systematic Review and Evidence Synthesis as A Practice and Scholarship Tool. In Rousseau, D.
(Ed.), The Oxford Handbook of Evidence-Based Management (pp. 112-129). New York, NY: Oxford University Press. doi: https://doi.org/10.1093/oxfordhb/97 $\underline{80199763986.013 .0007}$

Carson, D. (2010). Interface Research: A Commentary on A Commentary Ten Years On. Journal of Research in Marketing and Entrepreneurship, 12(1), 8-10. doi: https://doi.org/10.1108/1471520101 $\underline{1060902}$

Carson, D., \& Gilmore, A. (2000). Marketing at the Interface: Not 'What' but 'How.' Journal of Marketing Theory and Practice, 8(2), 1-7. doi: https://doi.org/10.1080/10696679.2 $\underline{000.11501863}$

Collinson, E., \& Shaw, E. (2001). Entrepreneurial Marketing - A Historical Perspective on Development and Practice. Management Decision, 39(9), 761766.

doi: https://doi.org/10.1108/EUM00000 $\underline{00006221}$

Duus, H. J. (1997). Economic Foundations for An Entrepreneurial Marketing Concept. Scandinavian Journal of Management, 13(3), 287305.

doi: https://doi.org/10.1016/S09565221(97)00004-3

Fiore, A. M., Niehm, L., Hurst, J., Son, J., \& Sadachar, A. (2013). Entrepreneurial Marketing: Scale Validation with Small, Independently-Owned Businesses. Journal of Marketing Development and Competitiveness, 7(4), 63-86. Diakses dari https://lib.dr.iastate.edu/aeshm_pub s/29/

Franco, M., Santos, M. D. F., Ramalho, I., \& Nunes, C. (2014). An Exploratory Study of Entrepreneurial Marketing 
in SMEs: The Role of The FounderEntrepreneur. Journal of Small Business and Enterprise Development, 21(2), 265-283. doi: https://doi.org/10.1108/JSBED-10$\underline{2012-0112}$

Gilmore, A. (2011). Entrepreneurial and SME Marketing. Journal of Research in Marketing and Entrepreneurship, 13(2), 137-145. doi: https://doi.org/10.1108/147152 01111176426

Hallbäck, J., \& Gabrielsson, P. (2013). Entrepreneurial Marketing Strategies During The Growth of International New Ventures Originating in Small and Open Economies. International Business Review, 22(6), 1008-1020. doi: https://doi.org/10.1016/j.ibusrev.20 $\underline{13.02 .006}$

Hill, J., \& Wright, L. T. (2000). Defining the Scope of Entrepreneurial Marketing: a Qualitative Approach. Journal of Enterprising Culture, 08(01), 23-46. doi: https://doi.org/10.1142/s021849580 0000036

Hills, G. E., \& Hultman, C. M. (2011). Academic Roots: The Past and Present of Entrepreneurial Marketing. Journal of Small Business and Entrepreneurship, 24(1), 1-10. doi: https://doi.org/10.1080/08276331.2 $\underline{011.10593521}$

Hills, G. E., Morgan, S., \& Hultman, C. M., Kraus, S., \& Schulte, R. (2010). History, Theory, and Evidence of Entrepreneurial Marketing - An Overview. International Journal of Entrepreneurship and Innovation Management, 11(1), 3-18. doi: https://doi.org/10.1504/IJEIM.2010. $\underline{029765}$

Hills, G. E., \& Hultman, C. (2013). Entrepreneurial Marketing: Conceptual and Empirical Research
Opportunities. Entrepreneurship Research Journal, 3(4), 437-448. doi: $\quad$ https://doi.org/10.1515/erj2013-0064

Hills, G. E., \& Laforge, R. W. (1992). Research at the Marketing Interface to Advance Entrepreneurship Theory. Entrepreneurship Theory and Practice, 16(3), 33-60. doi: https://doi.org/10.1177/1042258792 $\underline{01600303}$

Hills, G. E., Hultman, C. M., \& Miles, M. P. (2008). The Evolution and Development of Entrepreneurial Marketing. Journal of Small Business Management, 46(1), 99112. doi: https://doi.org/10.1111/j.1540627X.2007.00234.X

Hultman, C. M. (1999). Nordic Perspectives on Marketing and Research in The Marketing/Entrepreneurship Interface. Journal of Research in Marketing and Entrepreneurship, 1(1), 54-71. doi: https://doi.org/10.1108/1471520998 0001556

Ioniţă, D. (2012). Entrepreneurial Marketing: A New Approach for Challenging Times. Management \& Marketing Challenges for the Knowledge Society, 7(1), 131-150. Diakses dari http://www.managementmarketing. ro/pdf/articole/259.pdf

Jones, R., \& Rowley, J. (2009). Presentation of A Generic "EMICO" Framework for Research Exploration of Entrepreneurial Marketing in SMEs. Journal of Research in Marketing and Entrepreneurship, 11(1), 5-21. doi: https://doi.org/10.1108/1471520091 $\underline{1014112}$

Jones, R., \& Rowley, J. (2011). Entrepreneurial Marketing in Small Businesses: A Conceptual 
Exploration. International Small Business Journal, 29(1), 25-36. doi: https://doi.org/10.1177/0266242610 369743

Kraus, S., Eggers, F., Harms, R., Hills, G. E., \& Hultman, C. (2011). Diskussionslinien der Entrepreneurial MarketingForschung: Ergebnisse einer Zitationsanalyse. Z Betriebswirtsch, $81, \quad 27-58 . \quad$ doi: https://doi.org/10.1007/s11573-011$\underline{0509-0}$

Kraus, S., Filser, M., Eggers, F., Hills, G. E., \& Hultman, C. M. (2012). The Entrepreneurial Marketing Domain: A Citation and Co-Citation Analysis. Journal of Research in Marketing and Entrepreneurship, 14(1), 6-26. doi: https://doi.org/10.1108/1471520121 $\underline{1246698}$

Kraus, S., Harms, R., \& Fink, M. (2010). Entrepreneurial Marketing: Moving Beyond Marketing in New Ventures. International Journal of Entrepreneurship and Innovation Management (IJEIM), 11(1), 19-34. doi:

https://doi.org/10.1504/IJEIM.2010. $\underline{029766}$

Maritz, A., Frederick, H., \& Valos, M. (2010). A Discursive Approach to Entrepreneurial Marketing: Integrating Academic and Practice Theory. Small Enterprise Research, 17(1), 74-86. doi: https://doi.org/10.5172/ser.17.1.74

Miles, M. P., \& Darroch, J. (2006). Large Firms, Entrepreneurial Marketing Processes, and The Cycle of Competitive Advantage. European Journal of Marketing, 40(5-6), 485501.

doi: https://doi.org/10.1108/0309056061 0657804

Miles, M., Gilmore, A., Harrigan, P., Lewis, G., \& Sethna, Z. (2014).
Exploring Entrepreneurial Marketing. Journal of Strategic Marketing, 23(2), 94-111. doi: https://doi.org/10.1080/0965254X.2 $\underline{014.914069}$

Miller, D. (2011). Miller (1983) Revisited: A Reflection on EO Research and Some Suggestions for the Future. Entrepreneurship: Theory and Practice, 35(5), 873-894. doi: https://doi.org/10.1111/j.15406520.2011.00457.x

Morris, M. H., Schindehutte, M., \& LaForge, R. W. (2002). Entrepreneurial Marketing: A Construct for Integrating Emerging Entrepreneurship and Marketing Perspectives. Journal of Marketing Theory and Practice, 10(4), 1-19. doi:

https://doi.org/10.1080/10696679.2 $\underline{002.11501922}$

Morrish, S. C. (2011). Entrepreneurial Marketing: A Strategy for The Twenty-First Century?. Journal of Research in Marketing and Entrepreneurship, 13(2), 110-119. doi:

https://doi.org/10.1108/1471520111 $\underline{1176390}$

Morrish, S. C., \& Jones, R. (2020). PostDisaster Business Recovery: An Entrepreneurial Marketing Perspective. Journal of Business Research, 113, 83-92. doi: https://doi.org/10.1016/j.jbusres.20 $\underline{19.03 .041}$

Morrish, S. C., Miles, M. P., \& Deacon, J. H. (2010). Entrepreneurial Marketing: Acknowledging The Entrepreneur and Customer-Centric Interrelationship. Journal of Strategic Marketing, 18(4), 303316.

doi: https://doi.org/10.1080/0965254100 3768087

Mort, G. S., Weerawardena, J., \& Liesch, P. (2012). Advancing 
Entrepreneurial Marketing: Evidence from Born Global Firms. European Journal of Marketing, 46(3-4), 542-561. doi: https://doi.org/10.1108/0309056121 $\underline{1202602}$

Quinton, S., \& Harridge-March, S. (2006). The Interaction of Technology in Entrepreneurial Marketing: An Illustrative Case from A Wine Merchant. Strategic Change, 15(2), 85-102.

doi: https://doi.org/10.1002/jsc. 753

Reibstein, D. J., Day, G., \& Wind, J. (2009). Guest Editorial: Is Marketing Academia Losing Its Way?. Journal of Marketing, 73(4), $1-3$.

doi: https://doi.org/10.1509/jmkg.73.4.0 $\underline{01}$

Shaw, E. (2004). Marketing in The Social Enterprise Context: Is It Entrepreneurial?. Qualitative Market Research: An International Journal, 7(3), 194-205. doi: https://doi.org/10.1108/1352275041 0540209

Solé, M. (2013). Entrepreneurial Marketing: Conceptual Exploration and Link to Performance. Journal of Research in Marketing and Entrepreneurship, 15(1), 23-38. doi: https://doi.org/10.1108/JRME07-2012-0020

Stasch, S. F. (2002). Screening For Successful Low-Budget Marketing Strategies for New Ventures. Journal of Research in Marketing and Entrepreneurship, 4(3). doi: https://doi.org/10.1108/1471520028 $\underline{0001473}$

Stokes, D. (2000). Entrepreneurial Marketing: A Conceptualisation
From Qualitative Research. Qualitative Market Research, 3(1), 47-54.

doi: https://doi.org/10.1108/1352275001 $\underline{0310497}$

Stokes, D. (2000). Putting Entrepreneurship into Marketing: The Processes of Entrepreneurial Marketing. Journal of Research in Marketing and Entrepreneurship, 2(1), 1-16. doi: https://doi.org/10.1108/1471520008 $\underline{0001536}$

Swenson, M. J., Rhoads, G. K., \& Whitlark, D. B. (2012). Entrepreneurial Marketing: A Framework for Creating Opportunity with Competitive Angles. Journal of Applied Business and Economics, 13(1), 47-52. Diakses dari https://pdfs.semanticscholar.org/da2 e/bf10d5f8d95b5165d9d02b258221 02c8cd8f.pdf

Webb, J. W., Ireland, R.D., Hitt, M.A., Kistruck, G. M., \& Tihanyi, L. (2011). Where Is The Opportunity without The Customer? An Integration of Marketing Activities, The Entrepreneurship Process, and Institutional Theory. Journal of the Academy of Science, 39, 537-554. doi: https://doi.org/10.1007/s11747010-0237-y

Whalen, P., Uslay, C., Pascal, V. J., Omura, G., McAuley, A., Kasouf, C. J., \& Deacon, J. (2015). Anatomy of Competitive Advantage: Towards A Contingency Theory of Entrepreneurial Marketing. Journal of Strategic Marketing, 24(1), 5-19. doi:

https://doi.org/10.1080/0965254X.2 $\underline{015.1035036}$ 